\title{
Comparison of Situation in the Slovak and Czech Market of Milk and Dairy Products
}

\author{
Lubica Kubicová1, Kristína Predanocyová2, Zdenka Kádeková1, Ingrida Košičiarová1, Marek Dvořák \\ 1 Department of Marketing and Trade, Faculty of Economics and Management, Slovak University \\ of Agriculture in Nitra, Slovak Republic \\ 2 AgroBioTech Research Centre, Slovak University of Agriculture in Nitra, Slovak Republic \\ ${ }^{3}$ Department of Trade and Finance, Faculty of Economics and Management, Czech University of Life \\ Sciences Prague, Czech Republic
}

\begin{abstract}
The paper is focused on dairy sector with the emphasis on the development of consumption of milk and dairy products, including cheese, curd and other dairy products, in the last 15 years in the Slovak Republic and in the Czech Republic. The aim of the paper is to identify the level of milk and dairy products consumption, as well as to identify the main determinants affecting the consumption. Paper is also aimed at milk production with emphasis on the main problems that may affect future development on the dairy market. The primary data are obtained by consumer survey and survey aimed focused on producers of milk and dairy products. Based on the results we have identified that the milk and dairy products consumption by Slovak consumers is lower compared to the Czech Republic and the quality and price are considered as the main determinants influencing the consumption. We also found out that milk and dairy products producers are adapting their production to demand, but it is important to point out the barriers related in particular to the introduction of new technologies into production, rising input prices or growing consumer disinterest in the consumption of milk and dairy products.
\end{abstract}

\section{Keywords}

Slovak market, Czech market, milk, dairy products, consumption.

Kubicová, L., Predanocyová, K., Kádeková, Z., Košičiarová, I. and Dvořák, M. (2021) “Comparison of Situation in the Slovak and Czech Market of Milk and Dairy Products", AGRIS on-line Papers in Economics and Informatics, Vol. 13, No. 4, pp. 71-84. ISSN 1804-1930. DOI 10.7160/aol.2021.130407.

\section{Introduction}

Milk and dairy products can be generally considered as recommended food for all age categories of consumers that are very difficult to substitute, and with regard to children's consumers, their intake is irreplaceable. Milk and dairy products gain their importance also in international trade within the EU in in extra-EU trade (Yurik et al., 2020). For this reason, it is important to draw attention to children and the need to include milk and dairy products into their daily meals. Recognizing the need for milk by children of low age can lead to a positive relationship and a regular consumption of dairy foods even in adulthood (Kubicová et al, 2019).

Milk primarily intended for consumption can be characterized as a physiological fluid obtained from the mammary glands of agricultural mammals during the lactation period (Keresteš, 2016). In the conditions of the Slovak Republic and the Czech Republic, cow's, goat's and sheep's milk is processed. Cow's milk is the most widespread and distributed, so the paper focuses on this type of milk and on consumption aspects related to consumer behaviour on the market of milk and dairy products. The importance of the topic is based mainly on the need to address the current level of consumption due to its irreplaceable place in the nutrition of the population (Kubicová and Habánová, 2012).

Ware (2016) consider as a significant positive of cow's milk its content of a wide range of proteins, including all essential amino acids that have a beneficial effect on the growth and recovery of human muscle tissue. Cow's milk and high- 
fat milk products contain a sufficient amount of saturated fat, which can be considered as the energy source needed to increase the muscle mass in the body. Maintaining a healthy amount of muscle in the body is one of the basic prerequisites for promoting metabolism and ensuring optimal body weight. It can be said that by consuming of milk, consumers can increase their muscular mass and receive the energy they need to exercise and promote a healthy lifestyle. Based on a rational diet, milk and dairy products represent one of the most important food groups. In the context of the above milk could be defined as a complex balanced food (Špička et al., 2015; Maitah and Smutka, 2012; Čuboň et al., 2012; O’Neil and Fulgoni, 2009). Information on the composition of cow's milk is given in Table 1 .

\begin{tabular}{lc}
\hline Ingredient & $\mathbf{\%}$ \\
\hline Water & $87.0 \%$ \\
\hline Dry Matter & $13.0 \%$ \\
\hline Protein & $3.2 \%$ \\
\hline Lactose (carbohydrate) & $4.8 \%$ \\
\hline Fat & $4.2 \%$ \\
\hline Minerals & $0.8 \%$ \\
\hline
\end{tabular}

Source: own processing based on Obermaier and Čejna, 2013

Table 1: Composition of Cow's Milk \%.

Milk and dairy products can be generally considered as recommended food for all age categories of consumers that are very difficult to substitute, and with regard to children's consumers, their intake is irreplaceable (De Pelsmaeker et al., 2013). Milk is an important source of essential nutrients, such as vitamin D, calcium and magnesium (Nicklas et al., 2009) and milk consumption are associated with a reduced risk of mortality (Bongard et al., 2012). Milk and dairy products can be considered as products that help maintain good health, as a prevention of some diseases and also as a support in their treatment (Habánová et al., 2010).

Consumption of milk and dairy products has positive health effects for people (Košičiarová et al., 2017), which are mainly related to the development of the brain and nervous tissues. Garcia, Osburn and Cullor (2019) statet that dairy products have many benefits and are considered as key nutritious sources of proteins, fats and micronutrients with positive health impacts. Due to the fact, that milk contains minerals, especially phosphorus and calcium, milk consumption has a positive effect on the structure of bones and teeth (Rizzolli, 2016). Other proven effects of milk are a positive effect on the regulation of body temperature, as well as an effect on the intestinal microflora and bowel movement. Consumption of milk and dairy products strengthens muscle mass and growth, especially in early childhood (Geng et al., 2017) and has positive effects against obesity (Thorning et al., 2016). Moreover, live dairy cultures that are characterized by probiotic properties and biological value significantly affect nutritional metabolism and human health. Sour milk drinks with probiotic cultures as well as sour and matured cheeses are important in solving individual health problems, such as digestive problems, pressure problems, even cancer suppression, etc. (Rosa et al., 2017). There is increasing evidence suggesting that especially the fermented dairy products, cheese and yoghurt, are associated with a reduced risk of type 2 diabetes (Astrup, 2014).

In the context of a brief overview, the irreplaceable position of milk and dairy products in human nutrition can be deduced. In the Slovak Republic, the recommended consumption dose of milk and dairy products is at least $220 \mathrm{~kg}$ per person and per year, but in reality the milk consumption is only around $150 \mathrm{~kg}-160 \mathrm{~kg}$. This fact is alarming, and it is necessary to lead discussions related to consumption level and to propose measures to increase the consumption of healthy dairy products, mainly in the interests of public health. In connection with the above, the aim of the paper is to point out the development of milk and dairy consumption in the period 2009 to 2018 in the Slovak Republic in comparison with the Czech Republic and to identify the main determinants affecting the level of consumption as there is a knowledge gap in this field of research that needs to be fulfilled. This type of study is currently absent and it is very important to deal with the indicated aspects. Therefore, the presented scientific paper has a real potential to become a benefit for the scientific research area, as well as the analysed market of milk and dairy products.

\section{Materials and methods}

The aim of the paper was achieved by processing secondary data from the Statistical Office of the Slovak Republic (SO SR) and the Statistical Office of the Czech Republic (SO CR). The obtained secondary data are the basis for development of consumption of milk and dairy products until 2020 using the coefficient of determination $\mathrm{R}^{2}$, as well as for calculation of the average growth coefficient using $\mathrm{k}^{\prime}$. In the context of the above the regression analysis was applied and there 
were used linear, quadratic and cubic regression functions for express the trend in the development of annual consumption of milk and dairy products in the Slovak Republic and in the Czech Republic.

Primary data were obtained through consumer survey. The aim of survey was to identify the level of milk and dairy products consumption, as well as to identify the main determinants affecting the consumption. Survey was conducted on a sample of 516 respondents in Slovakia and was implemented in 2018 by electronic version. Respondents participating in the survey were diversified into 8 categories, by gender (women $64.1 \%$, males $35.9 \%$ ), age (up to 25 years $43.0 \%, \quad 26-35$ years $23.3 \%, \quad 36-50$ years $19.2 \%, 51-60$ years $8.5 \%$, more than 61 years $6.0 \%$ ), residence (countryside $48.6 \%$, city 51.4 ), education (basic 1.7\%, secondary school $45.9 \%$, university $52.3 \%$ ), economic status (student $36.2 \%$, employed $48.3 \%$, the self-employed person $4.7 \%$, unemployed $1.2 \%$, maternity leave $2.9 \%$, retired $6.8 \%$ ), monthly household income (less than 1,000 Euro 19.8\%, 1,001-2,000 Euro $54.7 \%$, 2,001-3,500 Euro 23.1\%, 3,501-4,500 Euro $2.1 \%$, more than 4,501 Euro $0.4 \%$ ), monthly income of respondents (less than 400 Euro 39.5\%, 401 - 800 Euro 39.3\%, 801 - 1,200 Euro 15.9\%, $1,201-1,600$ Euro 3.9\%, more than 1,601 Euro $1.4 \%)$. by the number of members of the household (1 member $3.7 \%$; 2 members $18.8 \% ; 3$ members $22.9 \%$; 4 members $37.6 \%$; 5 members $12.0 \%$; more than 5 members $5.0 \%$ ).

Primary data were obtained by the survey focused on milk and dairy producers. The aim was to find out information about production with emphasis on the main problems that may affect their future operation on the Slovak dairy market. The survey was realised in 2018 by personal and e-mail communications and was attended by 23 companies from Slovakia. Business entities were divided according to legal form of business (cooperative $43.5 \%$, joint stock company $21.7 \%$, limited liability company $13 \%$, self-employed farmer $13 \%$, selfemployed person $8.7 \%$ ), enterprise size (micro enterprise $30.4 \%$, small enterprise $21.7 \%$, medium enterprise $47.8 \%$ ) and type of produced milk (cow milk 91.3\%, sheep milk $26.1 \%$, goat milk 8.7\%).

For a deeper analysis of the research objectives, the following hypotheses were formulated:

Hypothesis 1: We assume that there exists the dependency between the level of milk and dairy products consumption and selected demographic criteria.
Hypothesis 2: We assume that consumers assess the importance of the individual criteria for consumption of milk and dairy products differently.

Hypothesis 3: We assume that there exists the dependency between the future level of milk and dairy products consumption and the current level of milk and dairy products consumption

The formulated hypotheses were tested by applying the following statistical tests: Chi-square test for independence of two variables; Cramer's coefficient; Friedman test. All the above-mentioned tests have been calculated in statistical software XL Stat. In hypothesis testing, if the p-value is lower than significant level 0.05 , the null hypothesis is rejected, and the alternative hypothesis is confirmed.

\section{Results and discussion}

Consumption of milk and dairy products has increased slightly in the long-term perspective, but still does not reach the required annual consumption at the level of the recommended doses. The mentioned is confirmed by the achieved values of monitored foods per capita in the Slovak Republic in the period 2009 - 2018. The development in consumption was accompanied by a slightly increasing trend and ranged from $153.8 \mathrm{~kg}$ to $171.1 \mathrm{~kg}$ per capita and year and the average growth in total annual consumption of milk and dairy products was on the level of $1.1 \%$ $\left(\mathrm{k}^{\prime}=1.011914\right)$. The largest increase in consumption was recorded in 2010, when consumption increased to $162.8 \mathrm{~kg}$, and compared to 2009 this meant an increase of $9 \mathrm{~kg}$. The change was caused by the implementation of the campaign "Objav mlieko", which had a great impact, especially on school-age consumers. After the end of the campaign, there was an immediate decrease in the consumption of milk and dairy products. Since 2011, there have been several attempts to increase consumption through various information and promotion campaigns aimed at motivating consumers to consume milk and dairy products (Slovenský zväz prvovýrobcov mlieka, 2020). Despite efforts, milk consumption is currently only $171.1 \mathrm{~kg}$. We have chosen a linear function that acquires the following parameters as a suitable function to describe the trend in the development of total consumption of milk and dairy products in the Slovak Republic:

$\mathrm{q}^{\mathrm{t}}=152.35+2.2721 * \mathrm{t} \quad \mathrm{R}^{2}=0.768$ 
The consumption of milk and dairy products is incomparably lower in comparison with the Czech Republic. Czech consumers consume milk and dairy products in the range that covers the range of recommended doses and in the observed period 2009-2018 reached the level of $249.7 \mathrm{~kg}$ to $245.8 \mathrm{~kg}$. The trend in the consumption of milk and dairy products was thus declining with an average annual decrease of $0.17 \%$ $\left(\mathrm{k}^{\prime}=0.998252\right)$. The stated values of consumption are achieved by the implementation of very successful promotion project "Bíle Plus" which was realised in 2010 - 2013. This project helped to eliminate negative trends in national consumption and revive its growth (Agrární komora České republiky). Based on the achieved results, the program was extended to other years and was also partially implemented in the Slovak Republic. We expressed the trend of the development of the total consumption of milk and dairy products in the Czech Republic in the years 2009 - 2018 by a cubic function with the following parameters:

$\mathrm{q}^{\mathrm{t}}=270.61-23.563 * \mathrm{t}+4.3766 * \mathrm{t}^{2}-0.227 * \mathrm{t}^{3}$

$\mathrm{R}^{2}=0.8586$

With a view to the future, it is possible to assume that in the next period there will be a continuing slightly increasing trend in the consumption of milk and dairy products in the Slovak Republic. Matošková and Gálik (2016) assume that the level of consumption will be influenced by the development of prices of milk and dairy products in relation to household income, gross domestic product and its distribution among the population, as well as living standards or individual consumer behaviour. In the Czech Republic a declining trend in the consumption of milk and dairy products is expected, which may be caused mainly by insufficient consumer information about the importance of milk consumption, as well as the spread of vegan lifestyle, or negative consequences of the current situation on the food market (Náš chov, 2020).

Milk, cheese, cottage cheese and sour milk products contribute to the total consumption of milk and dairy products the most. The development of milk consumption in the analysed period 2009 - 2018 had a declining trend from the long-term perspective (Figure 1). In the observed period, the average annual decrease was $0.81 \%$. In the first year, milk consumption was recorded at $49.5 \mathrm{~kg}$ per capita, but in the last year was only $46.0 \mathrm{~kg}$. The largest increase was recorded in 2010 and milk consumption waspositivelyaffected by thementioned promotional program. In the context of the above, it is important to emphasize that milk consumption has been eliminated to the current value since 2011. Milk consumption is lower compared to the recommended dose and lags behind by almost $50 \%$. This fact could be caused by the increasing milk prices and constantly expanding the range of dairy products, especially cheese, sour milk and other dairy products. We have chosen a linear function with the following parameters to express the trend in the development of milk consumption in the Slovak Republic in the period 2009 - 2018:

$\mathrm{q}^{\mathrm{t}}=54.293-0.8533 * \mathrm{t} \quad \mathrm{R}^{2}=0.631$

For comparison with the Czech Republic, it is important to emphasize that even the milk consumption by Czech consumers is not sufficient according to the recommendations of rational nutrition. Over the last 10 years, milk consumption has been recorded at about the same level with slight fluctuations. The average annual decline coefficient was recorded at only $0.02 \%$ $\left(\mathrm{k}^{\prime}=0.999814\right)$. We have chosen a cubic function with the following parameters to express

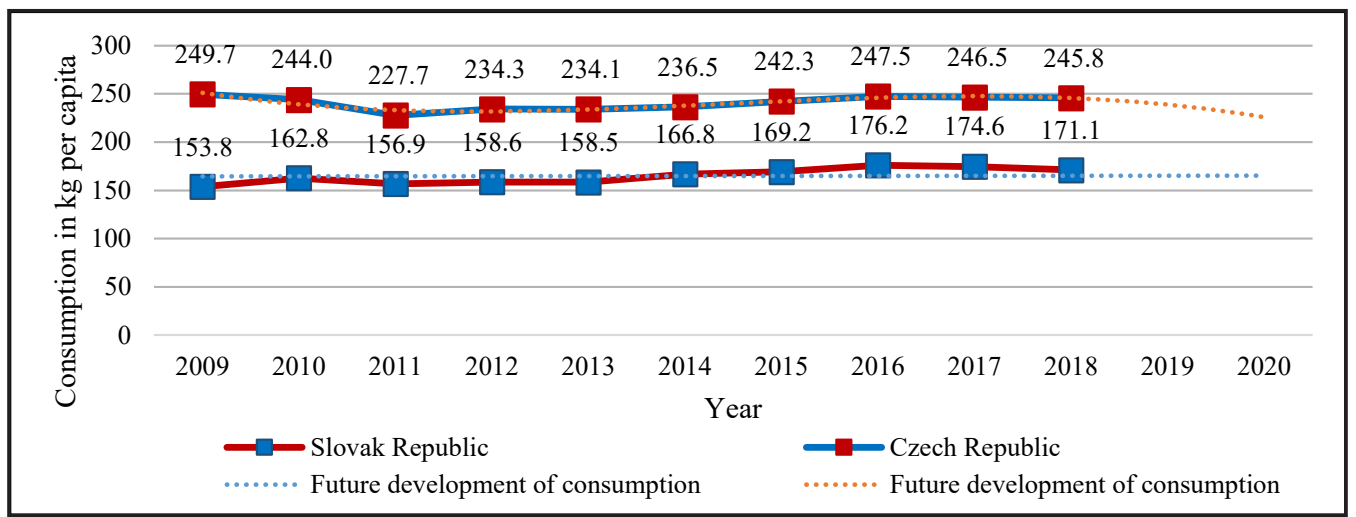

Source: own processing according to SO SR and SO CR

Figure 1: Comparison of the development trend of annual total consumption of milk and dairy products per capita and year in the Slovak Republic and in the Czech Republic. 
the trend of milk consumption in the Czech Republic in the years $2009-2018$ :

$$
\begin{aligned}
& \mathrm{q}^{\mathrm{t}}=60.4-1.7915 * \mathrm{t}+0.4999 * \mathrm{t}^{2}-0.0329 * \mathrm{t}^{3} \\
& \mathrm{R}^{2}=0.485
\end{aligned}
$$

We assume that in the next period there will be a continuing declining trend in milk consumption in the Slovak Republic and the Czech Republic, which may be caused not only by rising household incomes, rising milk prices, but also a relatively wide range of dairy products (Kubicová and Habánová, 2012). We expect a decrease in milk consumption to the level of approximately $43 \mathrm{~kg}$ per consumer in the Slovak Republic and approximately $54 \mathrm{~kg}$ per capita in the Czech Republic (Figure 2).

Consumption of cheese and curd had a slightly increasing trend in the observed period of 2009 2018 and the average annual growth of consumption was recorded at the level of $3.5 \%\left(\mathrm{k}^{\prime}=1,0345\right)$. In 2009 , consumption was at the level of $9.8 \mathrm{~kg}$ and in the last analysed year up to the level of $13.3 \mathrm{~kg}$, which represented an increase in consumption by $35.7 \%$. In comparison with the recommended doses of cheese consumption, the average annual consumption of cheese by Slovak consumers is sufficient. Despite the favourable development of consumption, the consumption of curd does not cover the recommended doses and lags behind by $12.5 \%$. The trend of the consumption of cheese and curd in the Slovak Republic in the years 2009 - 2018 was expressed by a linear function with the following parameters:

$\mathrm{q}^{\mathrm{t}}=8.64+0.5218 * \mathrm{t} \quad \mathrm{R}^{2}=0.8704$

The consumption of cheese and cottage cheese is at a sufficient level and covers the minimum amount of the recommended dose compared to the Czech Republic. The consumption of curd was gradually increased by an average of $0.8 \%$ $\left(k^{\prime}=1,0077\right)$ per year during the years 2009 and 2018 in the Czech Republic. In the first monitored period, the annual consumption of curd reached the level of $16.7 \mathrm{~kg}$ per capita, while in 2018 it increased by $7.2 \%$ to $17.9 \mathrm{~kg}$. The favourable development of the consumption of cheese and curd in the Czech Republic was positively influenced mainly by the constantly expanding range of curds, especially flavoured curds, which are becoming more and more popular among consumers. We have chosen a quadratic function with the following parameters to describe the trend in the development of annual curd consumption in the Czech Republic, $\mathrm{q}^{\mathrm{t}}=16.897+0.2447 * \mathrm{t}+0.0371 * \mathrm{t}^{2} \quad \mathrm{R}^{2}=0.8597$

Based on the development of consumption of cheese and curd on the Slovak and Czech market, we can evaluate and assume a gradually increasing interest of consumers in the consumption of unflavoured and flavoured curd. In the next two years in the Slovak Republic, we assume that the amount of consumed curd should approach the minimum limit of the recommended dose. In the case of the Czech Republic, we also assume a positive development and an increase in annual consumption to the level of approximately $5 \mathrm{~kg}$ per capita. The demand for cheese and curd should be influenced mainly by an increase in household income, expansion of curd assortment or increased preference and consumer awareness about the necessity of curd consumption. These aspects were also important according to Kubicová and Dobák (2012). In the next two years, we expect an increase in the consumption of cheese and curd by Slovak consumers by approximately $1.5 \mathrm{~kg}$ and by Czech consumers by $1.0 \mathrm{~kg}$ per year (Figure 3).

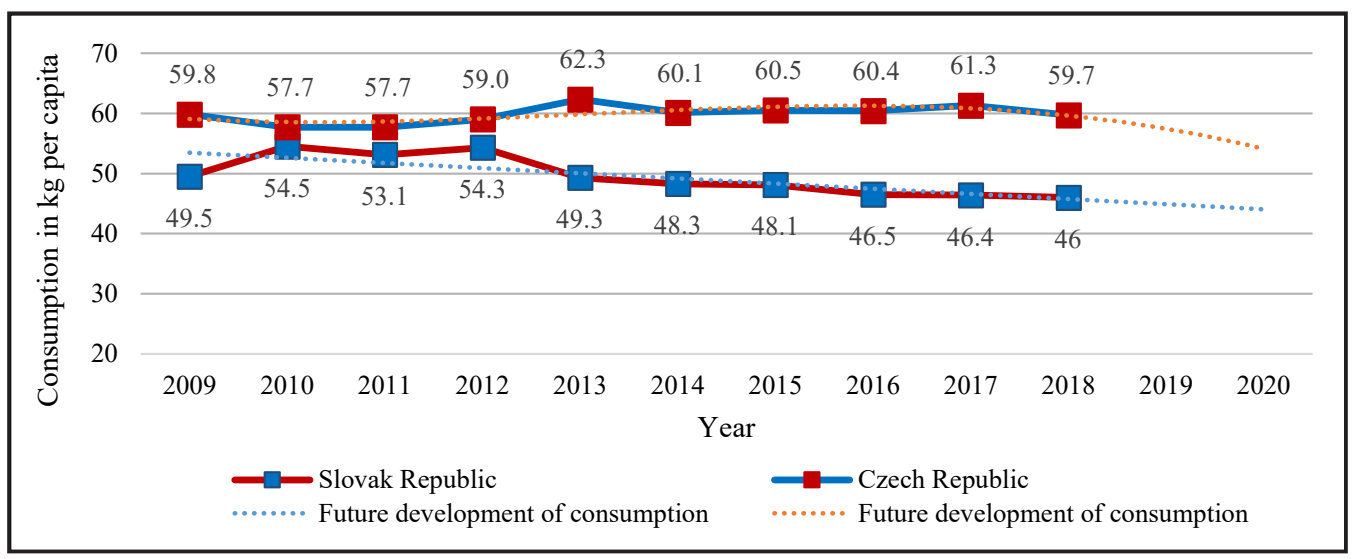

Source: own processing according to SO SR and SO CR

Figure 2: Comparison of the development trend of annual consumption of milk per capita and year in the Slovak Republic and in the Czech Republic. 


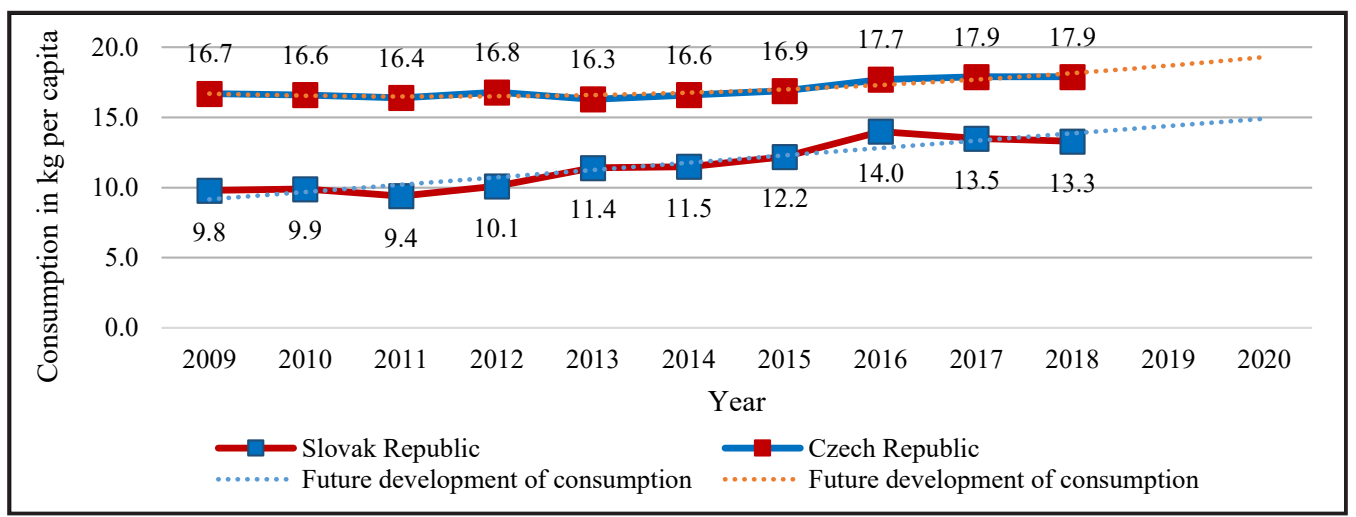

Source: own processing according to SO SR and SO CR

Figure 3: Comparison of the development trend of annual consumption of cheese and curd per capita and year in the Slovak Republic and in the Czech Republic.

Consumption of other dairy products by Slovak consumers, of which sour milk products are an important part, recorded a gradual increase in 2009 - 2018 with an average annual growth of $2.29 \%$. It is important to highlight the favourable growth in consumption by $48.8 \%$ from $13.7 \mathrm{~kg}$ in 2009 to $16.9 \mathrm{~kg}$ in the last year. The consumption of dairy products was recorded slightly below the level of the recommended dose of $14 \mathrm{~kg}$ until 2011. However, since 2012 it has increased and has reached the minimum level of recommended dose. Nowadays, consumption is approximately $20.0 \%$ above the recommendations for a rational diet. Yoghurts have a significant share on the other dairy products and their sales are growing due to the constantly expanding offer (Nouzovská, 2007). We chose a linear function with the following parameters to express the development trend of the annual consumption of other dairy products in the Slovak Republic in the observed period.

$\mathrm{q}^{\mathrm{t}}=12.8-0.4836 * \mathrm{t} \quad \mathrm{R}^{2}=0.881$

In the Czech Republic, the consumption of other dairy products was higher compared to the Slovak Republic. In the observed period 2009 - 2018 the annual consumption of other dairy products, especially sour milk products, ranged from $32.5 \mathrm{~kg}$ in 2010 and 2011 to $34.9 \mathrm{~kg}$ in the last observed year. The average annual consumption of other dairy products by Czech consumers is higher by almost $50.0 \%$ compared to the range of recommended doses. This fact may be caused by a wide range of dairy products, mainly yogurt and other sour milk products, that are becoming increasingly preferred by consumers. Moreover, the Czech Republic has one of the highest consumption of yoghurts and other sour milk products in Central Europe (Zemědelec, 2018). The cubic function with the following parameters was chosen to express the development trend of the annual consumption of other dairy products in the Czech Republic in the years 2009 - 2018:

$\mathrm{q}^{\mathrm{t}}=33.126-0.2759 * \mathrm{t}+0.0165 * \mathrm{t}^{2}+0.0065 * \mathrm{t}^{3}$

$\mathrm{R}^{2}=0.7435$

In the next two years, we expect gradually increasing consumption of these types of food. The level of consumption will be affected by rising consumer prices of sour milk products and other dairy products, household income, assortment of products, consumer prices of other dairy products, as well as the promotion of positive health effects. We assume the above on the basis of studies by Kubicová (2008), whose research was focused on a detailed examination of the development of consumer demand for sour milk products (Figure 4).

The consumer survey was conducted in connection with the analysis of the market of milk and dairy products in the Slovak Republic and was focused on identifying the amount of consumption of the monitored products, as well as the main factors determining the consumption. The results of the survey showed that only $0.4 \%$ of respondents do not consume milk or any dairy products, and they are probably consumers with lactose intolerance who are not looking for lactose-free alternatives to milk and dairy products. $10.4 \%$ of consumers annually consume milk and dairy products in the recommended interval, which is at the level of $206-240 \mathrm{~kg}$ per year. The results point to the fact that $56.2 \%$ of respondents consume less than $206 \mathrm{~kg}$ of milk and dairy products per year and $36.9 \%$ of consumers consume milk and dairy products excessively, above the level of $240 \mathrm{~kg}$. Slovak consumers most consume milk, sour milk products, cheese and curd and these products have 


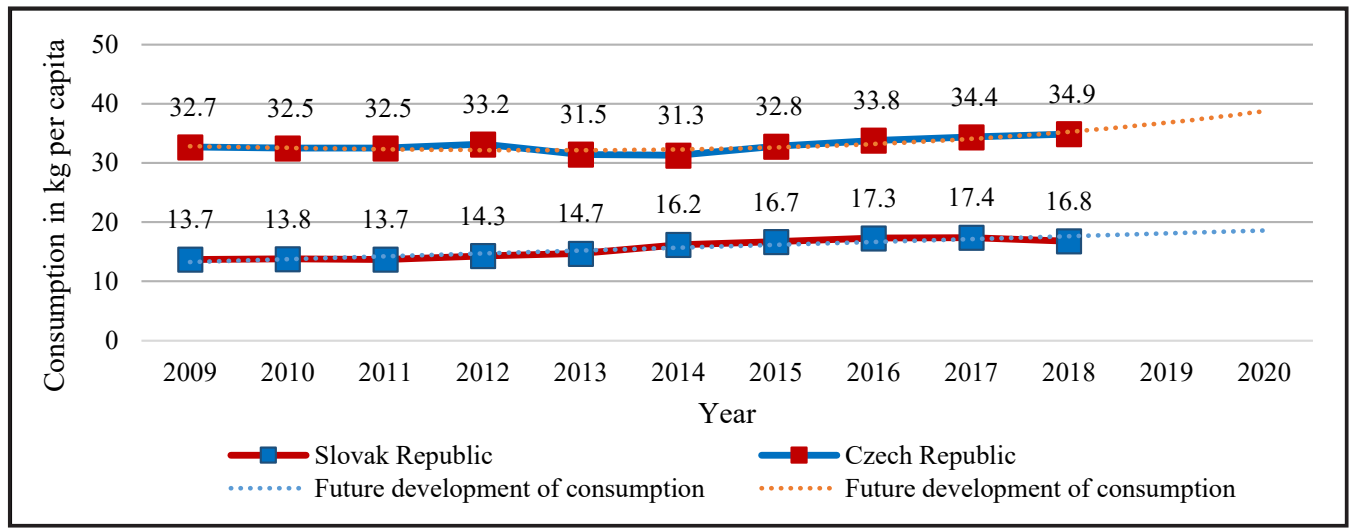

Source: own processing according to SO SR and SO CR

Figure 4: Comparison of the development trend of annual consumption of other dairy products per capita and year in the Slovak Republic and in the Czech Republic.

the largest share on total milk and dairy products consumption. In the context of this question, we assumed the dependence between the amount of consumption of milk and dairy products and selected demographic characteristics (age, gender, education, monthly household income). Based on the Chi test of square contingency, it can be stated that the dependence was confirmed only in the case of monthly household income $(p$-value $=0.006)$. From the aspect of dependence tightness, there is a very weak dependence proved by the calculation of the Cramer coefficient (0.119). Based on the above it could be concluded that the annual consumption of milk and dairy products depends on the monthly household income. However, it is very important to emphasize that most consumers from all income groups are characterized by insufficient consumption of the monitored products (Figure 5).

\begin{tabular}{l|c|c}
\hline & p-value & $\begin{array}{c}\text { Cramerov V } \\
\text { coefficient }\end{array}$ \\
\hline $\begin{array}{l}\text { Current consumption of milk } \\
\text { and dairy products and age } \\
\text { of respondents }\end{array}$ & 0.393 & - \\
\hline $\begin{array}{l}\text { Current consumption of milk } \\
\text { and dairy products and gender } \\
\text { of respondents }\end{array}$ & 0.121 & - \\
\hline $\begin{array}{l}\text { Current consumption of milk } \\
\text { and dairy products and education } \\
\text { of respondents }\end{array}$ & 0.251 & - \\
\hline $\begin{array}{l}\text { Current consumption of milk } \\
\text { and dairy products and household } \\
\text { monthly income }\end{array}$ & 0.0060 & 0.119 \\
\hline
\end{tabular}

Source: Statistical program XLSTAT, 2020

Table 2: The current level of consumption of milk and dairy products depending on selected demographic characteristics.

From the point of view of distribution to individual types of dairy products, it can be stated that the most consumed are cheese, curd, sour milk production and other dairy products. These are also confirmed by the results of the research of Kapsdorferová and Nagyová (2005), which was realised in Slovakia.

The results of our research showed that $10.0 \%$ of consumers do not consume milk. $52.7 \%$ of respondents consume an average of 0.01 to 0.2 liters of milk per day, which represents the amount of milk up to 21 grams. The recommended dose of milk consumption is at the level of 27 grams and the stated amount of milk is consumed by $9.5 \%$ of consumers. $18.1 \%$ of respondents consume 32 to 51 grams of milk per day and $9.7 \%$ of respondents state an average daily milk consumption of more than 52 grams, which in combination with relatively high consumption of other dairy products, can cause excessive milk consumption and dairy products.

The results of the survey also point to the consumption of cheeses and curds. Based on results it can be stated that only $4.4 \%$ of consumers consume the required amount of cheese and curds according to daily recommended doses (25-30 grams). It is also important to note that $4.1 \%$ of respondents do not consume cheese and curd at all and $23.7 \%$ of consumers consume them, but in insufficient quantities (less than 25 grams per day). On the other hand, the results show that almost $70 \%$ of respondents excessive consume curd and cheese, which could be justified by a wide range of cheese and curd.

Consumer research was also focused on the consumption of yoghurts, sour milk products and other dairy products. Based on the results, it can be stated that $9.3 \%$ of respondents consume dairy products daily in the range of recommended 


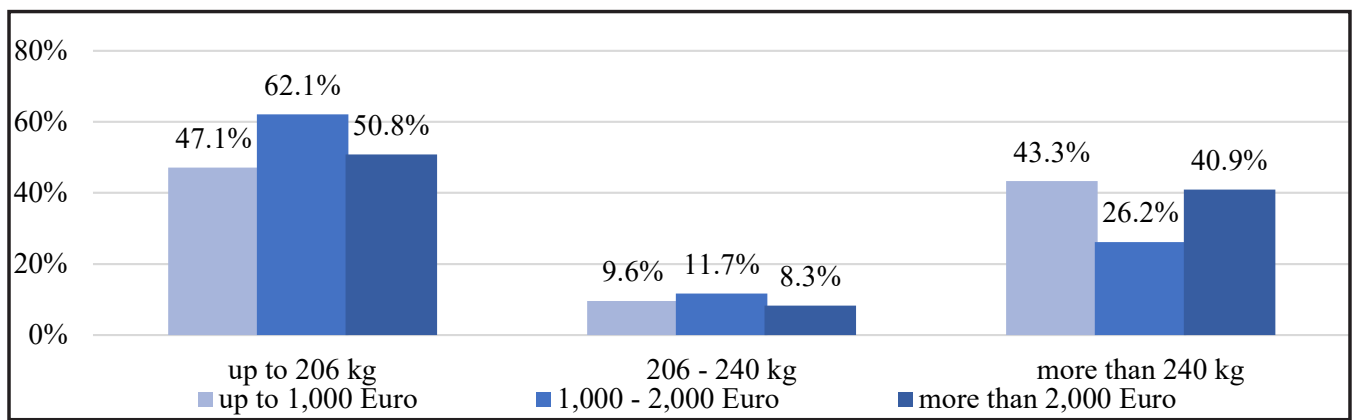

Source: consumer survey

Figure 5: Annual consumption of respondents according to household monthly income.

doses (75-90 grams). It is important to note that $7.7 \%$ of consumers do not consume sour milk and other dairy products and prefer milk, cheese and curd. On the other hand, $81.9 \%$ of respondents consume sour milk and other dairy products more than recommended doses and their average daily consumption is above 90 grams. High consumption could be caused mainly by a wide range of yoghurts, yoghurt milks, acidophilic milks, milk rice, kefir, or sour milks and probiotics. These products are preferred and looked for by consumers mainly because of taste and positive health effects.

In comparison with the Czech Republic, it can be noted that according to the research of Brazdová et al. (2014) cheese, milk, cream, cream yoghurts are the most consumed by Czech consumers and processed cheeses and low-fat yoghurts are the least preferred in consumption.

We have identified factors that are important for Slovak consumers in the issue of consumption of milk and dairy products. Koprda (2014) emphasizes that consumer behaviour is complex of behaviour that is not influenced by just one factor. Consumers rated ten factors that can determine their consumer behaviour on a scale of 1 to 4 , with 1 being the least important factor and 4 being the most important factor. Based on the results, it can be stated that quality (3.78), composition, durability and price are the most important factors for Slovak consumers. The GfK survey (2017) has shown that for the Slovak consumer is still a very important price when deciding about purchasing chosen food, including milk and dairy products, but the emphasis on quality is clearly rising. Other less important factors determining the consumption of milk and dairy products are nutrition information, country of origin, package size and producer. Consumers are least affected by the appearance of packaging (2.57) and promotion (2.73). Nagyová et al. (2020) concluded that consumers are unaffected by packaging, packaging material and brand at purchase and consumption. It follows from the above that we have confirmed the similarity and relevance of the results we have achieved. In the context of the evaluation of individual factors influencing the choice of monitored foods, we identified differences in the evaluation of determinants based on the Friedman test, which was statistically proven by the calculated $p$-value $(<0.0001)$. For comparison with the Czech Republic, it is possible to point out the example of Hes et al. (2009), who concluded in their study that the purchase and consumption of food, including milk and dairy products, is largely determined by the quality and properties of dairy products, as well as their price. In the context of the above, it could be concluded the comparable consumer behavior on the Slovak and Czech milk markets.

We identified an insufficient level of consumption and we were interested in the development of consumption of monitored foods over the next 5 years. It can be stated that $64.7 \%$ of consumers do not plan to change the amount of consumed milk and dairy products. $10.4 \%$ of respondents expect a decrease in the consumption of milk and dairy products and only $24.7 \%$ of respondents stated a planned increase in the consumption of milk and dairy products. In connection with this question, we assumed a dependence between the future consumption of milk and dairy products and the current consumption of milk and dairy products. Based on the Chi square contingency test, it can be stated that the dependence was confirmed $(p$-value $=0.0001)$. From the aspect of dependence tightness, there is a medium-strong dependence proved by the calculation of the Cramer coefficient (0.30) (Figure 6).

The future development of milk and dairy products consumption can be determined mainly by main factors such as price and quality of products, but also by the level of supply of milk and dairy 


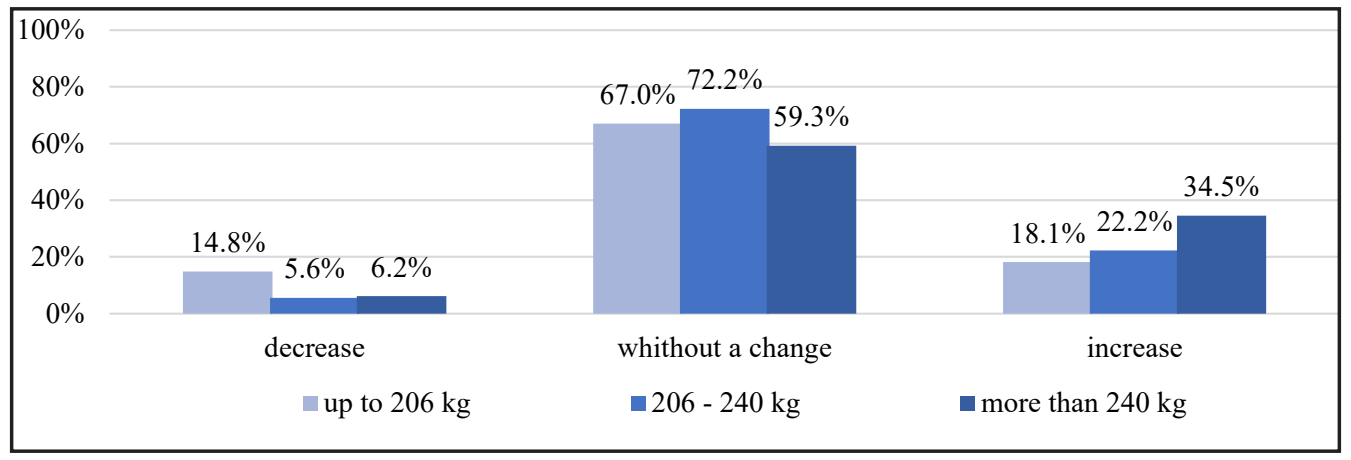

Source: consumer survey

Figure 6: Development of milk and dairy products consumption in the next 5 years according to current consumption of milk and dairy products.

products in the market.

The aim of the survey focused on producers of milk and dairy products was to map out the situation on the Slovak dairy market with an emphasis on production.

The entities are mainly focused on the production different types of cheese, including "parenice", "nite", "korbáčiky" and "oštiepky" (60.8\%), curd $(34.8 \%)$, yoghurts $(17.4 \%)$, butter $(17.4 \%)$ and cream (13.0\%). Enterprises focused on the production of dairy products use milk from their own resources $(82.6 \%)$, buy milk from Slovak local producers $(8.7 \%)$, or use a combination of the above options (8.7\%). On the issue of production, it is necessary to analyse the change in the amount of production over the last 5 years. The results showed that $65.2 \%$ of subjects have increased the production as a results of higher demand resulting from consumer interest in quality milk and dairy products, as well as of increased livestock and increased productivity, the introduction of modernization and new technologies into the production process or changes in the organizational structure of the company. On the other hand, $26.1 \%$ of entities have decreased the production as a result of the low purchase price of raw cow's milk, the cancellation of milk and dairy import quotas, reduction of dairy cows and reduction of productivity due to rising livestock costs or negative effects of agricultural policy.

In order to keep production volume of milk and dairy products with a tendency for growth, subjects use various forms of promotion with the emphasise on highlighting the milk origin, production process, traditional recipes, composition of dairy products without preservatives, quality of products, justification of product price and importance of consumption with positive health effects.
We also addressed milk and dairy products producers with a question concerning the problems of the dairy industry. It can be stated that the most significant problems are low state subsidies, milk quotas and high imports of foreign dairy products, low consumption, lack of interest in working in the dairy industry, unskilled labour, inability to use innovation in the production process and capital intensity of production technologies, high costs of milk production associated with low purchase prices of milk and high requirements for the production. Švikruhová et al. (2020) found that rising costs are also a problem for producers, either because of rising energy prices or because of rising labour costs caused by the government measures. In the Czech Republic Naglova et al. (2017) and Špička and Smutka (2014) identified another problem in production, which is related to strong pressure from foreign competition and has a negative impact on Czech companies operating in the dairy industry.

In order to address the situation on the dairy market, producers and processors have the possible suggestions in the form of higher support for domestic farmers by the state, financial subsidies, creating of suitable conditions for business entities, reduction of imports of milk and dairy products, or sales support for the Slovak dairy products with an appeal to increase the consumption of milk and dairy products. Horská et al. (2020) concluded that in order to keep and increase milk production, it is necessary to increase sales, which is possible by promoting the product itself with regard to its quality, freshness and location, as well as consumer recommendations and customer loyalty. Vasylieva (2017) found out that reducing retail prices and raising solvency of population would be the option for supporting the food industry, as well as effectively using quite big amount of public subsidies from the Rural Development Programme (Špička, 2015). 


\section{Conclusion}

The paper was focused on identifying the consumption of milk and dairy products in the Slovak Republic and the Czech Republic, the factors determining consumption, as well as the problems of milk and dairy products producers. Current consumption is at the level of $160 \mathrm{~kg}$ per capita and year, which does not cover even the recommended consumption dose. In terms of distribution between individual dairy products, we can conclude that there is a sufficient level of consumption in the case of sour milk products, yoghurts and other dairy products. For comparison with the Czech Republic, we found out that Czech consumers consume up to $250 \mathrm{~kg}$ of milk and dairy products on average per year, so the level of recommended consumption is reached. In the questionnaire survey realised in the Slovak Republic, we also examined the amount of consumed milk, cheese, curd and other dairy products by all respondents. Subsequently, the data were compared with the recommended consumption doses. In general, it can be stated that $56.2 \%$ respondents consume milk less than the level of the recommended doses, but the consumption of cheese, curd and other dairy products is higher compared to the recommended doses. It could be concluded, that $74.4 \%$ respondents consume cheese and curd in sufficient or excessive amount, and $91,2 \%$ respondents stated that they consume other dairy products mainly yogurts and sour-milk products in the level of recommended doses or their consumption is even higher. Based on the results, we have identified quality and price as the main determinants influencing milk and dairy products consumption. Slovak consumers consider these factors as the most important between ten evaluated factors on the scale from 1 to 4 according the importance. With a view to the future, it is probably possible that Slovak consumers will increasingly focus on products with higher added value. The results showed that $24.7 \%$ respondent are planning to increase their milk and dairy consumption. Milk and dairy products producers are adapting their production to demand, but it is important to point out the problems related in particular to the introduction of new technologies into production, rising input prices or growing consumer disinterest in the consumption of milk and dairy products. In comparison with the Czech Republic, it is possible to point out very similar consumer behaviour, while Czech consumers focus mainly on low-fat yoghurts. From the point of view of production, Czech producers identify identical problems as Slovak producers, which is confirmed by several Czech researches. In the market of milk and dairy products in both countries, we propose that measures be taken to support and maintain production and to ensure greater promotion in order to increase consumption, with an emphasis on quality, nutritional value and positive health effects. The paper reflected the current issues of the situation on the dairy market not only from the point of view of consumers but also from producers, and is becoming relevant for the scientific community as well as for the general public. The paper compared the situation on the Slovak and Czech market of milk and dairy products, which has acquired an international dimension and can be used as a basis for other scientific research and application. In the context of the above, it is necessary to constantly monitor the situation on the Slovak and Czech market of milk and dairy products. It is also necessary to carry out research that will be oriented towards consumers and producers on the milk and dairy products market, and thus it will be possible to anticipate the future perspective direction of dairy sector in the Slovak Republic and the Czech Republic. Currently we are facing new challenges of digital and technology transformation in all economies in the world (Rymarczyk, 2020; Młody, 2018; Sieja \& Wach, 2019), so next research should include also these issues into considerations, as the Industry 4.0 is connected also with a new model of a customer bahviour from the marketing perspective.

\section{Acknowledgements}

This work was supported by the Slovak Research and Development Agency on the basis of Contract no. APVV-16-0244 "Qualitative factors affecting the production and consumption of milk and cheese".

This publication was supported by the Operational Program Integrated Infrastructure within the project: Demand-driven research for the sustainable and innovative food, Drive4SIFood 313011V336, cofinanced by the European Regional Development Fund. 
Corresponding authors

doc. Ing. Lubica Kubicová, PhD.

Department of Marketing and Trade, Faculty of Economics and Management

Slovak University of Agriculture in Nitra, Tr. A. Hlinku 2, 94976 Nitra, Slovak Republic

Phone: +421 37641 4165, E-mail: kubicova.lubka@gmail.com

Ing. Kristína Predanócyová, PhD.

AgroBioTech Research Centre, Slovak University of Agriculture in Nitra

Tr. A. Hlinku 2, 94976 Nitra, Slovak Republic

Phone: +421 37641 4914,E-mail: kristina.predanocyova@gmail.com

\section{References}

[1] Agrární komora České republiky (2017) "Propagační program BÍLÉ PLUS úspěšně završen", February 2017. [Online]. Available: http://www.akcr.cz/txt/propagacni-program-bile-plus-uspesnezavrsen [Accessed: 10 February 2017]. (In Czech).

[2] Astrup, A. (2014) "A changing view on saturated fatty acids and dairy: from enemy to friend", The American Journal of Clinical Nutrition, Vol. 100, No. 6, pp. 1407-1408. ISSN 0002-9165. DOI 10.3945/ajen.114.099986.

[3] Bongard, V., Ruidavets, J. B., Simon, CH. and Dallongeville, J. (2012) "Consumption of milk is associated witha reduced risk of mortality in middle-aged men", Archives of Cardiovascular Diseases Supplements, Vol. 4, No. 1, p. 100. E-ISSN 1878-6502. DOI 10.1016/S1878-6480(12)70708-5.

[4] Brázdová, D. Z., Klimusová, H., Vorlová, L. and Fiala, J. (2014) "Food preference for milk and dairy products", Acta Veterinaria Brno, Vol. 83, No. 1, pp. S41-S44. ISSN 1801-7576. DOI 10.2754/avb201483S10S41.

[5] Čuboň, J., Haščík, P. and Kačániová, M. (2012) "Evaluation of raw materials and foodstuffs of animal origin (Hodnotenie surovín a potravín živočíšneho pôvodu)", Slovak University of Agriculture in Nitra, p. 381. ISBN-13: 978-80-552-0870-1. (In Slovak).

[6] De Pelsmaeker, S., Schouteten, J. and Gellynck, X. (2013) "The consumption of flavored milk among a children population: The influence of beliefs and the association of brands with emotions" Appetite, Vol. 71, No. 1, pp. 279-286. ISSN 0195-6663. DOI 10.1016/j.appet.2013.08.016.

[7] Garcia, S. N., Osburn, B. I. and Cullor, J. S. (2019) "A one health perspective on dairy production and dairy food safety", One Health, Vol. 7, No. 1, pp. 9. ISSN 2352-7714. DOI 10.1016/j.onehlt.2019.100086.

[8] Geng, T., Qi, L. and Huang, T. (2018) "Effects of Dairy Products Consumption on Body Weight and Body Composition Among Adults: An Updated Meta-Analysis of 37 Randomized Control Trials", Molecular Nutrition \& Food Research, Vol. 62, No. 1, pp. 1700410. ISSN 1613-4133. DOI 10.1002/mnfr.201700410.

[9] GFK (2017) "Ako sa mení slovenský spotrebitel", GFK, June 2017. [Online]. Available: https://www.gfk.com/sk/insights/tlacove-spravy/ako-sa-meni-slovensky-spotrebitel/ [Accessed: 14 June 2017]. (In Slovak).

[10] Golian, J., Nagyová, L., Andocsová, A., Zajác, P. and Palkovič, J. (2018) "Food Safety from Consumer Perspective: Health Safety", Potravinarstvo Slovak Journal of Food Sciences, Vol. 12, No. 1, pp. 313-322. ISSN 1337-0960. DOI 10.5219/917.

[11] Habánová, M., Lorková, M. and Kopčeková, J. (2010) "The consumption of acidophylus drinks and yogurts in selected population of pupils in years 2004 and 2008", Potravinarstvo Slovak Journal of Food Sciences, Vol. 4, No. 3, pp. 19-23. ISSN 1337-0960. DOI 10.5219/26.

[12] Horská, E., Petril'ák, M., Šedík, P. and Nagyová, L. (2020) "Factors Influencing the Sale of Local Products through Short Supply Chains: A Case of Family Dairy Farms in Slovakia", Sustainability, Vol. 12, No. 20. ISSN 2071-1050. DOI 10.3390/su12208499. 
[13] Kapsdorferová, Z. and Nagyová, L. (2005) "Consumer behavior at the Slovak dairy market. Spotrebitel'ské správanie na slovenskom trhu mlieka a mliečnych výrobkov", Agricultural Economics (AGRICECON), Vol. 51, No. 8, pp. 362-368. ISSN 1805-9295. DOI 10.17221/5120-AGRICECON. (in Slovak).

[14] Keresteš, J. (2016) "Mlieko vo výźive l'udí", Bratislava, Cad Press, p. 649. ISBN 978-80-88969-72-3. (In Slovak).

[15] Koprda, T. (2014) "Teoretické konštrukty spotrebitel'ského správania v marketingovej komunikácii", Nové výzvy masmediálnej a marketingovej komunikácie IV: a peer-reviewed collection of papers from the $4^{\text {th }}$ year of the scientific-professional seminar, University of Constantine the Philosopher in Nitra, pp. 5-11. ISBN 978-80-558-0756-0. (in Slovak).

[16] Košičiarová, I., Nagyová, L'. and Holienčinová, M. (2017) "Consumer behaviour on Slovak yoghurt and fermented milk products market", Acta Universitatis Agriculturae et Silviculturae Mendelianae Brunensis, Vol. 65, No. 6, pp. 1967-1978. ISSN 2464-8310. DOI 10.11118/actaun201765061967.

[17] Krešić, G., Herceg, Z., Lelas, V. and Režek Jambrak, A. (2010) "Consumers' behaviour and motives for selection of dairy beverages in Kvarner region: a pilot study", Mljekarstvo, Vol. 60, No. 1, pp. 50-58. ISSN 1846-4025.

[18] Kubelaková, A. and Šugrová, M. (2017) "Habit or choice? The decision - making process of young generation in purchasing dairy products in the Slovak Republic", International Day of Science 2017 - economics, management, innovation, Moravian University in Olomouc, pp. 113-120. ISBN 978-80-7455-060-7.

[19] Kubicová, L'. (2008) "Vývoj spotrebitel'ského dopytu po potravinách", Slovak University of Agriculture in Nitra, p. 85. ISBN 978-80-552-0092-7. (In Slovak).

[20] Kubicová, L. and Dobák, D. (2012) "Vývoj a úroveň spotreby mlieka a mliečnych výrobkov $v$ SR a modelovanie dopytu po potravinách vo vybraných skupinách domácnosti", Slovak University of Agriculture in Nitra. p. 88, ISBN 978-80-552-0821-3. (In Slovak).

[21] Kubicová, L'. and Habánová, M. (2012) "Development of milk consumption and marketing analysis of its demand", Potravinárstvo, Vol. 6, No. 4, pp. 66-72. ISSN 1337-0960. DOI 10.5219/236.

[22] Kubicová, L., Predanocyová, K. and Kádeková, Z. (2019) "The importance of milk and dairy products consumption as a part of rational nutrition", Potravinárstvo, Vol.13, No.4, pp. 234-243. ISSN 1337-0960. DOI 10.5219/1050.

[23] Maitah, M. and Smutka, L. (2012) "Economic analysis of milk production and consumption in the middle East and North Africa", Acta Universitatis Agriculturae Et Silviculturae Mendelianae Brunensis, Vol. 60, No. 4, pp. 245-254. ISSN 1804-1930. DOI 10.11118/actaun201260040245.

[24] Matošková, D. and Gálik, J. (2016) "Trh s mliekom a mliečnymi výrobkami a jeho prognóza do roku 2020”, Ekonomika polnohospodárstva, Vol. 16, No. 2, pp. 44-62. ISSN 1335-6186. (In Slovak).

[25] Młody, M. (2018) "New production patterns and the future of manufacturing relocation trend in the 4.0 era: The perspective of consumers", International Entrepreneurship Review, Vol. 4, No. 3, pp. 287-302. E-ISSN 2658-1841.

[26] Naglova, Z., Boberova, B., Horakova, T. and Smutka, L. (2017) "Statistical analysis of factors influencing the results of enterprises in dairy industry", Agricultural Economics, Vol. 63, No. 6, pp. 259 - 270. ISSN 1805-9295. DOI 10.17221/353/2015-AGRICECON.

[27] Nagyová, L., Šedík, P., Berčík, J., Petrilák, M. and Illés, C. B. (2020) "Factors Affecting Purchasing and Consumption Behaviour: A Case Study of Slovak Milk Market", International Scientific Days 2020, Innovative Approaches for Sustainable Agriculture and Food Systems Development, pp. 148-154. DOI 10.18515/dBEM.ISD.P01.2020.p016.

[28] Náš chov (2020) "Vývoj trhu s mlékem je výrazně ovlivněn pandemií covid-19", Náš chov. [Online]. Available: https://www.naschov.cz/vyvoj-trhu-s-mlekem-je-vyrazne-ovlivnen-pandemii-covid-19/ [Accessed: 08 June 2020]. 
[29] Nicklas, T. A., O'neil, C. E. and Fulgoni III, V. L. (2009) "The role of dairy in meeting the recommendations for shortfall nutrients in the American diet", Journal of the American College of Nutrition, Vol. 28, No. 1, pp. 73S-81S. ISSN 1541-1087 DOI 10.1080/07315724.2009.10719807.

[30] Nouzovská, Z. (2007) "The importance of milk in human nutrition", Mliekarstvo: Bulletin pre internú potrebu výrobcov a spracovatel'ov mlieka, Vol. 38, No. 3, pp. 20-22. ISSN 1210-3144.

[31] Obermaier, O. and Čejna, V. (2013) "How do we know the quality? Cheese and curd (Jak poznáme kvalitu? Sýry a tvarohy), Prague, Association of Czech Consumers, o. s, 15 p. ISBN 978-80-87719-06-0. (In Czech).

[32] Rizzoli R. (2014) "Dairy products, yogurts, and bone health", The American Journal of Clinical Nutrition, Vol. 99, No. 5, pp. 1256S - 1262S. ISSN 0002-9165. DOI 10.3945/ajcn.113.073056.

[33] Rymarczyk, J. (2020) "Technologies, Opportunities and Challenges of the Industrial Revolution 4.0: Theoretical Considerations", Entrepreneurial Business and Economics Review, Vol. 8, No. 1, pp. 185-198. ISSN 2353883X. DOI 10.15678/EBER.2020.080110.

[34] Sieja, M. and Wach, K. (2019) "The Use of Evolutionary Algorithms for Optimization in the Modern Entrepreneurial Economy: Interdisciplinary Perspective", Entrepreneurial Business and Economics Review, Vol. 7, No. 4, pp. 117-130. ISSN 2353883X. DOI 10.15678/EBER.2019.070407.

[35] Skořepa, L. (2009) "Regionální trh potravin", České Budejovice, Jih pro Jednotu, s. d., 196 p. ISBN 978-80-8626-618-3. (In Czech).

[36] Slovenský zväz prvovýrobcov mlieka (2020) "Mliečny fond", Slovenský zväz prvovýrobcov mlieka. [Online]. Available: https://szpm.sk/mliecny-fond [Accessed: 08 November 2020].

[37] Statistical Office of the Czech Republic (2020) "Spotřeba potravin", Statistical Office of the Czech Republic. [Online]. Available: https://www.czso.cz/csu/czso/spotreba-potravin-2018 [Accessed: 06 Nov. 2020].

[38] Statistical Office of the Slovak Republic (2020) "Databases", Statistical Office of the Slovak Republic. [Online]. Available: https://slovak.statistics.sk/wps/portal/ext/Databases [Accessed: 06 Nov. 2020].

[39] Šedík, P., Berčík, J., Nagyová, L., Horská, E. and Tatar, E. (2020) "Consumer Behaviour towards Traditional Slovak Cheese "Parenica"", International Scientific Days 2020, Innovative Approaches for Sustainable Agriculture and Food Systems Development, pp. 174-180. ISBN 978-963-269-918-9.

[40] Špička, J. and Smutka, L. (2014) "The technical efficiency of specialised milk farms: A regional view", Scientific World Journal, Vol. 2014. ISSN 1537-744X. DOI 10.1155/2014/985149.

[41] Špička, J., Smutka, L. and Selby, R. (2015) "Recent areas of innovation activities in the Czech dairy industry", Agricultural Economics, Vol. 61, No. 6, pp. 249-264. ISSN 805-9295. DOI 10.17221/128/2014-AGRICECON.

[42] Švikruhová, P., Kapsdorferová, Z. and Kataníková, R. (2020) "The Current Situation and Needs of Milk Producers in the Slovak Republic", International Scientific Days 2020, Innovative Approaches for Sustainable Agriculture and Food Systems Development, pp. 181-188. ISBN 978-963-269-918-9.

[43] Thorning, T. K., Raben, A., Thorning, T., Soedamah-Muthu, S. S., Givens, I. and Astrup, A. (2016) "Milk and dairy products: good or bad for human health? An assessment of the totality of scientific evidence", Food \& Nutrition Research, Vol. 60, No. 1. ISSN 1654-661X. DOI 10.3402/fnr.v60.32527.

[44] Yurik, S., Pushkin, N., Yurik, V., Halík, J. and Smutka, L. (2020) "Analysis of Czech Agricultural Exports to Russia Using Mirror Statistics", Entrepreneurial Business and Economics Review, Vol. 8, No. 2, pp. 27-46. ISSN 2353883X. DOI 10.15678/EBER.2020.080202. 
[45] Zemědělec (2018) "Spotřeba mléčných výrobků loni v ČR klesla", Zemědělec. [Online]. Available: https://www.zemedelec.cz/spotreba-mlecnych-vyrobku-loni-v-cr-klesla/ [Accessed: 22 August 2018].

[46] Ware, M. (2016) "Milk: Health Benefits and Nutritional Information", Medical News Today, [Online]. Available:http://www.medicalnewstoday.com/articles/273451. php / [Accessed: 16 March 2020]. 